\title{
EFFECT OF PLASMA NITRIDING PROCESS CONDITIONS ON CORROSION RESISTANCE OF 440B MARTENSITIC STAINLESS STEEL
}

\author{
Magdalena ŁĘPICKA*, Małgorzata GRĄDZKA-DAHLKE* \\ ${ }^{*}$ Faculty of Mechanical Engineering, Department of Materials and Biomedical Engineering, Bialystok University of Technology, \\ ul. Wiejska 45 C, 15-351 Białystok, Poland \\ magdalena.lepicka@gmail.com, m.dahlke@pb.edu.pl
}

\begin{abstract}
Martensitic stainless steels are used in a large number of various industrial applications, e.g. molds for plastic injections and glass moldings, automotive components, cutting tools, surgical and dental instruments. The improvement of their tribological and corrosion properties is a problem of high interest especially in medical applications, where patient safety becomes a priority. The paper covers findings from plasma nitrided AISI 440B (PN-EN or DIN X90CrMoV18) stainless steel corrosion resistance studies. Conventionally heat treated and plasma nitrided in $\mathrm{N}_{2}: \mathrm{H}_{2}$ reaction gas mixture (50:50,65:35 and 80:20, respectively) in two different temperature ranges $\left(380\right.$ or $\left.450^{\circ} \mathrm{C}\right)$ specimens groups were examined. Microscopic observations and electrochemical corrosion tests were performed using a variety of analytical techniques. As obtained findings show, plasma nitriding of AISI 440B stainless steel, regardless of the process temperature, results in reduction of corrosion current density. Nevertheless, applying thermo-chemical process which requires exceeding temperature of about $400^{\circ} \mathrm{C}$ is not recommended due to increased risk of steel sensitization to intergranular and stress corrosion. According to the results, material ion nitrided in $450^{\circ} \mathrm{C}$ underwent leaching corrosion processes, which led to significant disproportion in chemical composition of the corroded and corrosion-free areas. The authors suggest further research into corrosion process of plasma nitrided materials and its degradation products.
\end{abstract}

Key words: Stainless Steels, Corrosion, Surface Modification Techniques, Plasma Nitriding, Surgical Instruments

\section{INTRODUCTION}

The improvement of performance of martensitic stainless steels is a problem of high interest. Martensitic stainless steels are used in a large number of various industrial applications, e.g. molds for plastic injections and glass moldings, automotive components, cutting tools, surgical and dental instruments (Pinedo and Monteiro, 2004; Wu, et al., 2010). The improvement of their tribological and corrosion properties is a problem of high interest especially in medical applications. Necessity to undergo cyclical sterilisation processes and intermittent contact with hard tissues and body fluids (Marciniak, 1992; Paszenda and TyrlikHeld, 2003) create unusually hard working conditions. Due to that reassurance of patient safety becomes a priority for medical instruments manufacturers.

Plasma nitriding, also referred to as ion nitriding, is a thermochemical surface treatment used in industry for more than 30 years (Soltani Asadi and Mahboubi, 2012) to treat especially steels. Its main aim is to introduce elemental nitrogen to the surface of a metal part for subsequent diffusion into the material (Sirin and Kaluc, 2012; Mashreghi et al., 2013). As a result, nitrogen-rich phases form at the steel's surface (Basu et al., 2008) - a compound, "white" layer and a diffusion zone (Sirin and Kaluc, 2012; Mashreghi et al., 2013). The outer and considerably thinner layer (usually ca. $25 \mu$ thick) (Podgornik et al., 1998) consists of $\mathrm{y}^{\prime}-\mathrm{Fe}_{4} \mathrm{~N}$ or $\varepsilon-\mathrm{Fe}_{2,3} \mathrm{~N}$ inter-metallic phases (Sirin and Kaluc, 2012; Mashreghi et al., 2013). It is commonly called as "white layer" due to its white colour after Nital etch on the mictoscopy or, simply, referred to as "compound layer" (Sirin and Kaluc, 2012). On the other hand, the diffusion zone consists of a nitrogen rich solid solution and fine coherent nitride precipitates (Sirin and Kaluc, 2012; Mashreghi et al., 2013). The studies have shown that both $\mathrm{y}^{\prime}-\mathrm{Fe}_{4} \mathrm{~N}$ or $\varepsilon-\mathrm{Fe}_{2,3} \mathrm{~N}$ are characterised by excellent tribological characteristics and good corrosion properties ( $\mathrm{Li}$ and Bell, 2008; Xi et al., 2008a; Xi et al., 2008b; Zhao et al., 2012; Mashreghi et al., 2013). Their proportion in the nitride-affected layer depends upon the plasma activity, treatment duration, microstructure of the sample and its temperature (Tuckart et al., 2007). Although the compound layer has a relatively high hardness of 950-1200 HV, the high internal stresses between the various lattice structures make it brittle, which can lead to spalling during service (Podgornik et al.,1998). Tuckart et al. (Tuckart et al., 2007) have shown that after some incubation time, even without any external disturbance, cracks are generated and propagate in the nitride layers.

In the previous work (Łępicka and Grądzka-Dahlke, 2013), the effect of heat treatment and plasma nitriding on the corrosion resistance of AISI 440B martensitic stainless steel has been investigated. The results showed that plasma nitriding does not significantly affect AISI 440B martensitic stainless steel corrosive characteristics as far as the uniform nitride layer over the entire detail surface is obtained. Therefore, in this study the effects of plasma nitriding in various nitrogen to hydrogen ratios on the corrosion resistance of AISI 440B martensitic stainless steel have been evaluated.

\section{MATERIALS AND METHODS}

As in the previous research (Łępicka and Gradzka-Dahlke, 2013), the AISI 440B (PN-EN X90CrMoV18) stainless steel was 
selected for further analyses. Chemical composition of the substrate is presented in Tab. 1.

Tab. 1. 440B stainless steel chemical compotision (wt $\%$ )

\begin{tabular}{|c|c|c|c|c|c|}
\hline & C & $\mathrm{Mn}$ & Si & $S$ & $P$ \\
\hline EDX & $\mathrm{n} / \mathrm{o}$ & 0.74 & 0.84 & - & 0.03 \\
\hline $\begin{array}{c}\text { PN-EN } 10088 \\
-1: 2005\end{array}$ & $\begin{array}{c}0.85 \\
\div 0.95 \\
\end{array}$ & $\begin{array}{l}\max \\
1.00 \\
\end{array}$ & $\begin{array}{l}\max \\
1.00 \\
\end{array}$ & $\begin{array}{l}\max \\
0.040\end{array}$ & $\begin{array}{c}\max \\
0.030\end{array}$ \\
\hline & $\mathrm{Cr}$ & Mo & V & $\mathrm{Fe}$ & \\
\hline EDX & 19.25 & 0.98 & 0.09 & balance & \\
\hline $\begin{array}{c}\text { PN-EN } 10088 \\
-1: 2005\end{array}$ & $\begin{array}{c}17.00 \\
\div 19.00\end{array}$ & $\begin{array}{c}0.90 \\
\div 1.30\end{array}$ & $\begin{array}{c}0.07 \\
\div 0.12\end{array}$ & balance & \\
\hline
\end{tabular}

The research material has been prepared accordingly to the manufacturing process of surgical drill bits. Specimens were heat treated and plasma nitrided. The effect of plasma nitriding conditions on subjected material corrosion resistance has been investigated.

Specimens were subjected to heat treatment, consisting of quenching in oil, from an austenitising temperature of $1030^{\circ} \mathrm{C}$, and tempering. The tempering temperature is extremely important when considering desired properties of the steel. Tempering in low temperatures (up to $250^{\circ} \mathrm{C}$ ) provides the highest hardness. However, the following procedure, plasma nitriding, is performed at higher temperatures.

Specimens were prepared in the form of discs with $8 \mathrm{~mm}$ diameter and $6 \mathrm{~mm}$ height. Pre-cut material was subjected to two-phase heat treatment: quenching in oil, from austenitising temperature of $1030^{\circ} \mathrm{C}$, and tempering in $250^{\circ} \mathrm{C}$. The substrate material has been finished by means of sandblasting, what is typical for surgical instruments manufacturing process.

The as-received samples were divided into 7 groups and subjected to 6 plasma nitriding processes, differing in the process temperature and working gases concentrations. The plasma nitriding process was carried out at 380 or $450^{\circ} \mathrm{C}$ temperature, under the working pressure of $200 \mathrm{~Pa}$. The nitriding process, as earlier, lasted 2 hours. In order to determine the most promising treatment conditions, the authors chose three concentrations of working gases, namely:

a) $50 \% \mathrm{H}, 50 \% \mathrm{~N}$, i.e. $100 \mathrm{ml} / \mathrm{min}_{2}+100 \mathrm{ml} / \mathrm{min} \mathrm{N} 2$,

b) $65 \% \mathrm{H}, 35 \% \mathrm{~N}$, i.e. $130 \mathrm{ml} / \mathrm{min} \mathrm{H}_{2}+70 \mathrm{ml} / \mathrm{min} \mathrm{N}_{2}$,

c) $80 \% \mathrm{H}, 20 \% \mathrm{~N}$, i.e. $160 \mathrm{ml} / \mathrm{min} \mathrm{H}_{2}+40 \mathrm{ml} / \mathrm{min} \mathrm{N}_{2}$.

All analysed samples are summarised in Tab. 2. The reference material was non-treated AISI 440B martensitic stainless steel (Tab. 2, series 7).

The obtained materials corrosive characteristics were demarcated using computer controlled ATLAS 9833 (Atlas-Sollich) corrosion system. Potentiodynamic polarisation scans with constant scan rate of $0.001 \mathrm{~V} / \mathrm{s}$ were performed in open to air, maintained at $21^{\circ} \mathrm{C} 0.9 \mathrm{wt} \% \mathrm{NaCl}_{\mathrm{aq}}$ solution. The electrode set consisted of a saturated calomel electrode (SCE, $0.242 \mathrm{~V}$ in $25^{\circ} \mathrm{C}$ vs SHE at $\left.25^{\circ} \mathrm{C}\right)$, platinium auxiliary electrode $\left(31.4 \mathrm{~mm}^{2}\right.$ contact surface) and a AISI 440B martensitic stainless steel sample, which circular area of $50.24 \mathrm{~mm} 2$ contacted with the testing solution. Tests were performed as follows: (I) cleansing sample from debris in filled with ethyl alcohol bath ultrasonic cleaner, (II) rinsing metallic specimen with distilled water, (III) placing the prepared sample in a three-neck flask pre-filled with $250 \mathrm{~cm}^{3} 0.9 \%$ $\mathrm{NaCl}_{\text {aq }}$ solution, (IV) stabilization for 120 minutes, (V) performance of polarisation scan from $-0.6 \mathrm{~V}$ to potential of up to $+2 \mathrm{~V}$. The corrosion potential ( $\left.E_{\text {corr }}\right)$, corrosion current logarithm (log $\left.\mathrm{i}_{\text {corr }}\right)$
(Tafel method) and the pitting potential $\left(E_{p}\right)$ were determined.

Tab. 2. Specimens summary table

\begin{tabular}{|c|c|c|}
\hline $\begin{array}{c}\text { Series } \\
\text { no. }\end{array}$ & $\begin{array}{c}\text { Plasma nitriding } \\
\text { process temperature } \\
\left({ }^{\circ} \mathrm{C}\right)\end{array}$ & Gaseous mixture concentration \\
\hline 1 & \multirow{3}{*}{380} & $50 \% \mathrm{~N}_{2}+50 \% \mathrm{H}_{2}$ \\
\hline 2 & & $35 \% \mathrm{~N}_{2}+65 \% \mathrm{H}_{2}$ \\
\hline 3 & & $20 \% \mathrm{~N}_{2}+80 \% \mathrm{H}_{2}$ \\
\hline 4 & \multirow{3}{*}{450} & $50 \% \mathrm{~N}_{2}+50 \% \mathrm{H}_{2}$ \\
\hline 5 & & $35 \% \mathrm{~N}_{2}+65 \% \mathrm{H}_{2}$ \\
\hline 6 & & $20 \% \mathrm{~N}_{2}+80 \% \mathrm{H}_{2}$ \\
\hline 7 & Reference sample & Without modification \\
\hline
\end{tabular}

The post-test samples pit and morphology structure were studied by scanning electron microscopy (SEM - Hitachi S-3000N microscope), confocal laser scanning microscopy (CLSMO - Olympus LEXT OLS 4000 microscope) and energy-dispersive $X$-ray analyser (EDX).

\section{RESULTS AND DISCUSSION}

The applied thermo chemical treatment parameters resulted in a change in the corrosion resistance of tested steels, as shown in Figs. 1-6.

The first group of investigated samples consisted of specimens plasma nitrided at temperatures in the range of $380^{\circ} \mathrm{C}$ (Fig. 1). First and foremost, it can be observed that the reactive gas composition has a minor impact on corrosion characteristics; curves which present ion nitrided material almost overlap. It is vital that regardless of the reaction gas mixture, with respect to the non-nitrided specimen, the corrosion potential of plasma nitrided material shifts towards the less noble values. However, the corrosion currents of modified samples is about twice lower. What is more, pitting potential (Ep $\approx 1 \mathrm{~V}$ for series 2 and series 3 ) is observed only for samples ion nitrided in low-nitride gas mixture.

A similar trend can be observed considering steel plasma nitrided in higher temperatures (Figure 2). As in the previous case, the corrosion currents of modified specimens are significantly lower than the one of the reference material. The lower the corrosion current is, the lower the corrosion rate of the considered material occurs. However, pitting potential can be noticed for both modified specimens at the potential of ca. $900 \mathrm{mV}$. As it was mentioned in the previous work (Łępicka and Graqdzka-Dahlke, 2013), heat treatment of martensitic stainless steels in temperatures exceeding $420^{\circ} \mathrm{C}$ may lead to deterioration of their corrosion characteristics. For that reason, the low-temperature (LTN) plasma nitriding ought be suggested in mass production rather than the high-temperature one.

As it can be seen in Fig. 3, the reference material is distinguished by the most positive corrosion potential, and, at the same time, the highest corrosion rate of all considered samples. The plasma nitriding process, irrespective of the reactive gas composition, results in reduction of the corrosion processes rate. The best results are obtained when using the low-temperature process. Clearly, this kind of surface modification has its drawbacks, emerging mainly from the difficulties connected with designing the high-effective mass production process, but its advantages stand out among all demerits. The main one is ability to obtain 
improvement in corrosion characteristics without sacrificing hardness of the modified detail. It is an extremely important factor when considering thermo-chemicall process application in surgical drill bits production. The operational part of that type of surgical tools ought be characterised mainly by high hardness and adequate wear resistance.

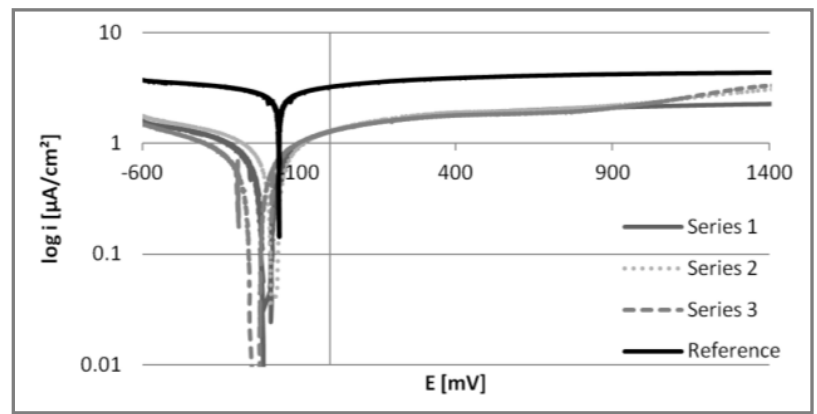

Fig. 1. Polarisation curves of plasma nitrided in $380^{\circ} \mathrm{C} 440 \mathrm{~B}$ steel in $0.9 \mathrm{wt} \% \mathrm{NaCl}$ solution (undeaerated, unstirred)

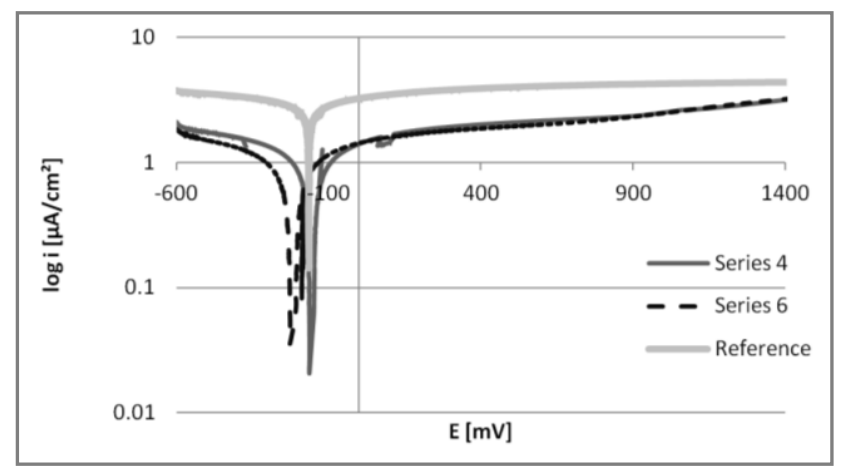

Fig. 2. Polarisation curves of plasma nitrided in $450^{\circ} \mathrm{C} 440 \mathrm{~B}$ steel in $0.9 \mathrm{wt} \% \mathrm{NaCl}$ solution (undeaerated, unstirred)

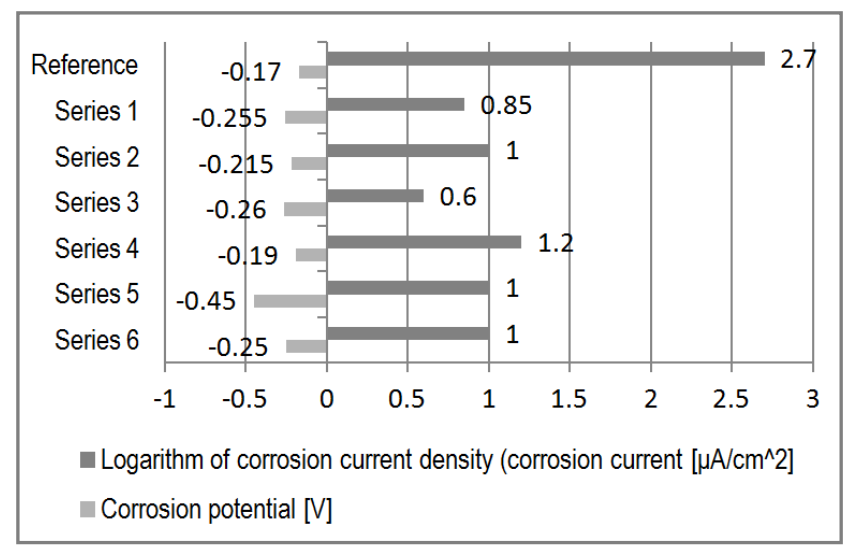

Fig. 3. Selected corrosion potentials and logarithms of corrosion currents densities of the examined samples

Fig. 4 presents surface morphology of the reference sample after potentiodynamic test. As it can be seen, even at the magnification of $1000 \times$ no corrosion pits can be distinguished - only traces of machining are visible. Chemical composition of the specimen, mesured by the means of EDX, covers the chemical composition of ISO standard AISI 440B martensitic stainless steel.

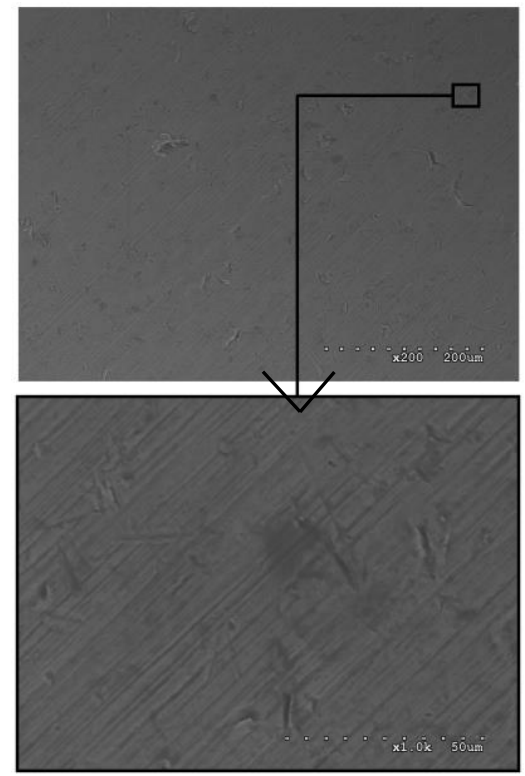

Fig. 4. Surface morphology of the reference material. SEM images, 200 and $1000 \times$ magnification

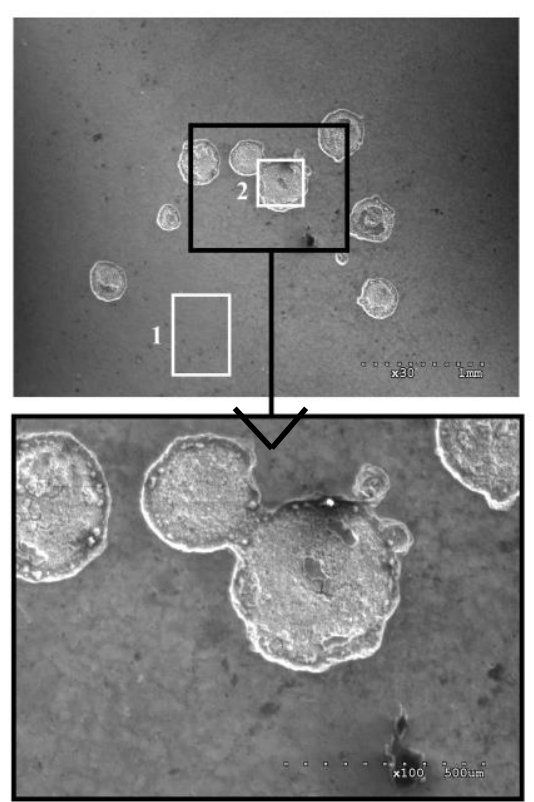

Fig. 5. Series 4 sample after potentiodynamic test. SEM images, 30 and $100 \times$ magnification; 1 - non-corroded surrounding material, 2 - pit area

Tab. 3. Chemical composition of areas presented in Fig. 5 (wt $\%$ )

\begin{tabular}{|c|c|c|c|c|c|}
\hline & C & $M n$ & Si & $S$ & $\mathbf{P}$ \\
\hline Area no. 1 & $\mathrm{n} / \mathrm{o}$ & 0.77 & 0.96 & - & 0.04 \\
\hline \multirow[t]{2}{*}{ Area no. 2} & $\mathrm{n} / \mathrm{o}$ & 1.05 & 0.49 & - & 0.02 \\
\hline & $\mathrm{Cr}$ & Mo & $\mathrm{V}$ & $\mathrm{Fe}$ & \\
\hline Area no. 1 & 19.55 & 1.10 & 0.07 & 77.52 & \\
\hline Area no. 2 & 45.21 & 2.50 & 0.17 & 50.56 & \\
\hline
\end{tabular}

Plasma nitrided specimens surface morphology significantly differs from the reference one. First and foremost, corrosion pits of circular shape are visible even with the unaided eye (Fig. 5). Surface condition suggests that, as opposed to the reference 
material, uniform corrosion processes were not present. What is more, the corrosion pits areas are chromium-rich and low in iron (Tab. 3). This suggests selective dissolution of alloying elements. This phenomenon can occur e.g. when chromium carbides are present in a stainless steel alloy. In such case, the adjacent to the carbides, low in chromium areas become the anodic, highly susceptible to corrosion processes regions. High disproportion between the anode and cathode areas size and quantity leads to dynamic material dissolution at the grain boundaries (Łępicka and Gradzka-Dahlke, 2013). Next possible scenario assumes that the material reached its pitting potential, as it was mentioned before. Continuity of obtained in the thermo-chemical process nitride layer was broken, leading to a rapid iron dissolution. Corrosion pits gradually increased in size and depth, causing the observed damages visibility.

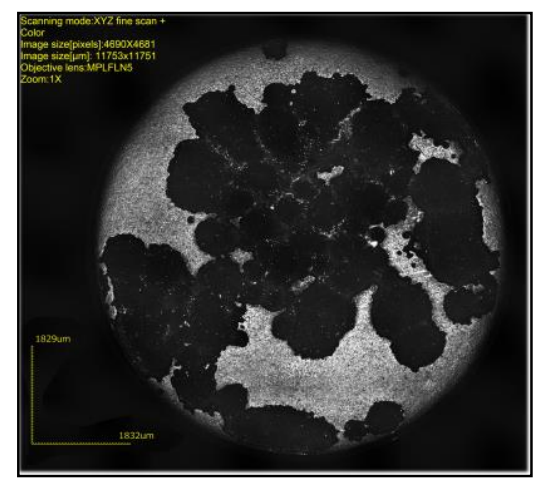

Fig. 6. Series 5 sample after potentiodynamic test. CLSMO image.

What is important, such disproportions in chemical composition were observed only for material ion nitrided in $450^{\circ} \mathrm{C}$ (Series 4-6). Knowing that the higher temperature of the thermal process is, the bigger is the risk of making martensitic stainless steel susceptible to intergranular corrosion, this finding suggests that chromium carbides were highly likely to precipitate. If indeed so, selective leaching, often referred to dealloying or selective corrosion, occured.

Similar findings were obtained for other series nitrided in $450^{\circ} \mathrm{C}$. Fig. 6 presents macroscopic view of series 5 sample. Depth of the corrosion pits, measured by the means of CLSMO microscope, reached up to $7 \mu \mathrm{m}$.

\section{SUMMARY}

The aim of the conducted study was to evaluate corrosion resistance of $440 \mathrm{~B}$ type martensitic stainless steel after plasma nitriding in two different process temperatures. According to the literature, ion nitriding in $380^{\circ} \mathrm{C}$ is recommended in manufacturing process rather than plasma nitriding in higher temperatures due to increased likelihood of fatigue and stress corrosion occurrence after applying thermo-chemical process in temperatures exceeding $400^{\circ} \mathrm{C}$. Received research results confirm these theses.

The obtained findings analysis enabled authors to draw following conclusions:

- With regard to the reference material, plasma nitriding results in reduction of corrosion current density, that is it helps reducing corrosion processes rate.

- The lower nitrogen ratio in the gaseous mixture is, the better anticorrosive properties material exhibits.
- Further analysis into corrosion processes and degradation products of plasma nitrided material is suggested.

\section{REFERENCES}

1. Basu A., Dutta Majumdar J., Alphonsa J., Mukherjee S., Manna I. (2008), Corrosion resistance improvement of high carbon low alloy steel by plasma nitriding, Materials Letters, Vol. 62, No. 17-18, 3117-3120.

2. Łępicka M., Grądzka-Dahlke M. (2013), Effect of Heat Treatment and Plasma Nitriding on Corrosion Resistance of X90CrMoV18 Martensitic Stainless Steel, Acta Mechanica et Automatica, Vol. 7 , No. 3, 155-159.

3. Li C. X., Bell T. (2006), Corrosion properties of plasma nitrided AISI 410 martensitic stainless steel in $3.5 \% \mathrm{NaCl}$ and $1 \% \mathrm{HCl}$ aqueous solutions, Corrosion Science, Vol. 48, No. 8, 2035-2049.

4. Mashreghi A. R., Soleimani S. M., Saberifar S. (2013), The investigation of wear and corrosion behavior of plasma nitrided DIN 1.2210 cold work tool steel, Materials and Design, Vol. 46, 532-538.

5. PN-EN 10088-1:2005, Stainless steels, List of stainless steels.

6. PN-EN ISO 7153-1:2002, Surgical instruments, Metallic materials. Stainless steel.

7. PN-EN ISO 8044:2002, Corrosion of metals and alloys - Basic terms and definitions.

8. Podgornik B., Vizintin J., Leskovsek V. (1998), Tribological properties of plasma and pulse plasma nitrided AISI 4140 steel, Surface and Coatings Technology, Vol. 108-109, 454-460.

9. Sirin S. Y., Kaluc, E. (2012), Structural surface characterization of ion nitrided AISI 4340 steel, Materials and Design, Vol. 36, 741-747.

10. Soltani Asadi Z., Mahboubi F. (2012), Effect of component's geometry on the plasma nitriding behavior of AISI 4340 steel, Materials and Design, Vol. 34, 516-521.

11. Tuckart W., Forlerer E., lurman L. (2007), Delayed cracking in plasma nitriding of AISI 420 stainless steel, Surface \& Coatings Technology, Vol. 202, No. 1, 199-202.

12. Wu K., Liu G. Q., Wang L., Xu B. F. (2010), Research on new rapid and deep plasma nitriding techniques of AISI 420 martensitic stainless steel, Vacuum, Vol. 84, No.6, 870-875.

13. Xi Y., Liu D., Han D. (2008a), Improvement of corrosion and wear resistances of AISI 420 martensitic stainless steel using plasma nitriding at low temperature, Surface \& Coatings Technology, Vol. 202, No. 12, 2577-2583.

14. Xi Y., Liu D., Han D. (2008b), Improvement of erosion and erosioncorrosion resistance of AISI420 stainless steel by low temperature plasma nitriding, Applied Surface Science, Vol. 254, No. 18, 5953-5958.

15. Zhao Y., Yu B., Dong L., Du H., Xiao J. (2012), Low-pressure arc plasma-assisted nitriding of AISI 304 stainless steel, Surface and Coatings Technology, Vol. 210, 90-96.

Acknowledgements: This scientific work was partially supported by the Faculty of Mechanical Engineering, Bialystok University of Technology, project No MB/WM/13/2014, and by European Union Funds in the R\&D project "Modification of operating characteristics of surgical instruments" conducted under the "Technology Transfer to Industry" project.

Author Magdalena Łępicka is a beneficiary of the project "Scholarships for PhD students of Podlaskie Voviodeship". The project is co-financed by European Social Fund, Polish Government and Podlaskie Vovoideship.

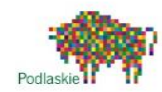

UNIA EUROPEJSKA
EUROPESKKI
FUNDUSZ SPOKECZNY

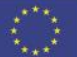

